\title{
Impacts and consequences of residential segregation of Roma in urban spaces: Case studies from Hungary
}

This article explores residential segregation and its characteristics in medium-sized and small towns in the Southern Great Plain statistical region of Hungary. The study highlights the main features and driving forces of segregation connected to post-communist urban development. We are approaching this from the perspective of the following questions: How are segregation processes connected to ethnic issues and living conditions? What can the local government do to solve this problem? The article concludes that residential segregation is a frequent phenomenon in Hungarian agro-towns. These processes share some similarities but also differ to some degree from western European or US examples. The results emphasise the importance of complex thinking about social integration, local planning and more effective financial allocation.

Keywords: residential segregation, medium-sized and small towns in post-communist countries, Roma ethnic minority, urban development 


\section{Introduction}

Segregation is a well-researched and widely known social phenomenon that can involve various social groups based on race, ethnicity, religion, sexual identity or other factors, and it has a variety of manifestations, from educational to occupational and residential segregation (e.g., White, 1983; Massey \& Denton, 1993; Clark \& Ware, 1997; Marcuse, 1997; Bjorvatn \& Cappelen, 2001; Charles, 2003; Musterd, 2003; Zhang, 2006; Logan \& Stults, 2011). This article examines the features of residential, housing or geographical segregation in medium-sized and small towns in Hungary's Southern Great Plain statistical region. Residential segregation is generally well observed and documented in large cities of the United States and western Europe, whereas much less is known about the characteristics of this process in post-communist countries, especially in towns with a population below two hundred thousand (e.g., Gentile, 2004; Gyenizse et al., 2016). Residential segregation was a defining phenomenon of the historical development of the settlements examined, and our results indicate that it is still present in their urban life. It is not as conspicuous as in larger cities - just like in the case of urban poverty and rural poverty - but it is a crucial problem to solve in order to achieve a sustainable future.

The accession of the eastern European post-communist countries to the European Union has offered many advantages in terms of the further progress of various development policies. One of these is urban planning, in which the professionals had to leave behind the mainly technical approach from the era of state socialism and had to integrate new aspects and methods into planning practice. Thus social problems, conflicts and their effect on urban land use attracted more attention. In the EU's previous and current planning period, towns were required to prepare an "integrated urban development strategy," which was an indispensable condition for receiving EU subsidies for towns. One of the obligatory elements of this strategic development document is an anti-segregation plan for the settlement. The requirements for this are based on EU legislation and recommendations and thematically mainly focus on residential segregation, using a common methodology for delimiting and describing the segregated areas. Earlier only county seats and other towns with county rights had to make such plans, but in the preparation for the 2014-2020 programming period the Hungarian government extended this obligation to the centres of micro-regions as well. This provides the opportunity for comprehensive analysis of residential segregation in medium-sized and small towns in Hungary. We selected towns in the Southern Great Plain statistical region and the town of Kecskemét for more detailed exploration because we had previous research experience in this area and our research team had participated in preparing some regional and urban strategic and planning documents (e.g., the 2008 Integrated Urban Development Strategy for Kecskemét and its 2013 revision, the 2008 Anti-Segregation Plan for Kecskemét and its 2013 and 2017 revisions, Innoaxis HU-SRB IPA, Lolamar HU-SRB IPA, the 2013 Development Concept for Bács-Kiskun County, a complex 2012-2013 rural research programme based on cooperation between the Hungarian Academy of Sciences and the Hungarian National Rural Network, the 2013 Strategy for Scattered Farms in the Kecskemét Microregion, and the 2017 Labour Market Assessment in Bács-Kiskun County).

Our research questions are the following:

- How frequent is residential segregation in medium-sized and small towns of the Southern Great Plain statistical region? Where can these neighbourhoods be found in these towns?

- What are the main features and driving forces of residential segregation? Is it possible to identify any characteristics that are uniquely connected to post-communist urban development in a medium-sized town?

- How are these processes connected to ethnic issues and living conditions?

-What can the local government do to solve this problem?

\section{Theoretical background}

"At a general level, residential segregation is the degree to which two or more groups live separately from one another, in different parts of the urban environment" (Massey \& Denton, 1988: 282). However, at different levels of multicoloured reality, segregation (parallel with polarisation and exclusion) is an extremely diverse process, and its consequences form a variety of spatial patterns (Park et al., 1925; Burgess, 1928; Duncan \& Duncan, 1955a, 1955b; Glazer \& Moynihan, 1963; Lieberson, 1963; Taeuber \& Taeuber, 1965; Morgan \& Norbury, 1981; Hamnett, 2005, 2010). According to the volume Residential segregation in comparative perspective: Making sense of contextual diversity, residential segregation is a multidimensional social phenomenon that is closely related to the spatial separation of social groups within a settlement and the socio-environmental disparities between various areas and neighbourhoods (Maloutas \& Fujita, 2012).

Residential or socio-spatial segregation is usually caused by various factors. These factors can be general ones such as economic changes, or local ones such as urban area and infrastructure development, but some authors state that the racial or ethnic division of the society is one of the most powerful among these (Musterd \& Ostendorf, 1998; Márquez, 2011; Bolt et al., 2012; Lloyd et al., 2014; Sabater \& Finney, 2014). 
In addition, this residential segregation is strongly associated with income inequalities between social or ethnic groups in the society, but many authors agree that this correlation is also reproduced in the characteristics of the built environment (Schelling, 1971, 1978; Charles, 2001; Logan et al., 2004; Watson, 2006; Spielman \& Harrison, 2013; Anthopolos et al., 2014; Bellman, 2014). We would like to closely investigate this phenomenon in this article. Wealthier groups of local societies try to separate themselves from disadvantaged people as much as possible. This induces a self-reinforcing spiral and continuously strengthens the spatial differences within a town.

We also accept the hypothesis that "residential segregation is a global construct" and that social differences have a similar spatial form in the US, western Europe and the post-communist countries (Massey \& Denton, 1988). "Social inequity and its spatial outcome, residential differentiation or segregation, exists in all advanced societies" (Vaattovaara, 2002: 108). Because of this we believe the previously identified conflicts and processes of the early twentieth century in the international literature can also be applied to the contemporary occurrences (Duncan \& Duncan, 1957; Howell \& Timberlake, 2014). These case studies show a strong analogy with the recent residential segregation processes of eastern European towns, from social conflicts to spatial patterns (Kovács, 2012). Racial segregation, which has been studied in the United States since the early twentieth century, strongly resembles the emergence of ghettos in eastern European towns (Farley et al., 1997). Under recent Hungarian conditions, this means that a significant part of the Roma population lives in poor conditions and segregation. This raises the old question again: are there general driving forces of residential segregation, or do local conditions determine the differences between urban areas? The results of our research may also provide additional information to answer this question.

\section{The historical roots of residential segregation in Hungarian towns}

Although residential segregation in Hungary is not solely a phenomenon related to the status of the Roma population, its most pressing present-day issues usually involve Roma. Therefore, this brief historical overview also mainly focuses on their situation over the centuries. Before 1848, residential segregation based on legal position (noble or peasant villages), religion (Jewish neighbourhoods) and ethnicity (German or Slovak towns and villages) was common in feudal Hungary. After the Ottoman era, which ended around 1700, the formerly nomadic Roma found their place in this system when they gradually settled down in Hungary. The reign of Empress Maria Theresa (1740-1780) facilitated this process and it also prohibited the spatial segregation of the Roma population. Despite this, the first Roma settlements were established during this period (Csalog, 1984). These settlements were located in places less favoured for construction, such as areas threatened by floods or upwelling groundwater, or near dumps or cemeteries (Kállai \& Törzsök, 2006). The recent street names in these areas still show the historical function of these locations. At the beginning of the twentieth century, $90 \%$ of the Roma population lived in residential segregation. At the same time, the position of the Roma in the labour market was weakened. Some traditional professions that played an important role in employing the Roma were rapidly losing significance (Csalog, 1984). During the interwar period, the largescale restructuring of the labour market and the Great Depression also pushed a large part of society into underclass conditions and forced them into neighbourhoods similar to the Roma areas. In addition to these, other special residential segregation types existed in Hungary, such as the cottagers' settlements of the manors or the cave houses in Bükkalja (Illyés, 1936; Szabó, 1937). These cave houses were initially inhabited by poor peasants, but over subsequent decades Roma became the new residents (Kemény, 2000).

After the Second World War, the new communist regime was able to improve the living conditions of the most deprived and reduce social inequalities. Forced Stalinist industrialisation (despite all of its anomalies) was able to employ the labour force leaving the primary sector and it also managed to integrate the Roma in this process. Even the idealistic communist target of full employment was reached for Roma men in this period (Csalog, 1984). Unlike labour market integration, the elimination of residential segregation started very sluggishly. This was partly related to the rapid spatial expansion of the towns, which reduced the spatial isolation of the peripheral slums from the town. The centrally planned elimination of Roma neighbourhoods and settlements started much later, only after the resolution of the Hungarian Socialist Workers' Party in 1961, which was a milestone in the process (Kocsis \& Kovács, 1999). The actual planning activities included the liquidation of many settlements that had existed for centuries, and due to these efforts the living conditions of the Roma population at least partly improved. Despite the aforementioned results, the basic objectives of the programme, such as the elimination of residential segregation or closing the gap in living conditions, could not be achieved because of the following reasons:

- Although some Roma neighbourhoods avoided demolition, they were also left out of even the most basic infrastructure development because of the central policy of displacement.

- Some local authorities ignored the regulation about the scattered resettlement of the Roma population and quite 
often moved them to places with similar unfavourable geographical attributes. In these locations, new closed blocks with only low-standard housing (coded $C s$ in Hungarian) were built, which could not close the gap between the living conditions of the majority and the Roma. Nowadays Dankó Pista utca (Pista Dankó Street) preserves the memory of these events in the Hungarian settlements (Csalog, 1984).

- In some cases, these displaced people moved to far worse conditions because they received new homes on farmsteads that had lost their function due to collectivisation.

In addition to the new closed blocks of $C s$ housing, there were other factors that also facilitated the spatially shifted reproduction of residential segregation. One of these was the conditions of the loan request to buy a house. The maximum amount of the loan was only enough to buy real estate in small villages with decreasing population and poor accessibility. As a result, the affected settlements underwent a rapid population change. Settlements with stronger lobbying capacity strengthened this process with the displacement of their Roma population to these villages (Havas, 1999). This practice led to the formation of a Roma majority in several settlements, especially in the Cserehát and Ormánság regions (Ladányi \& Szelényi, 2004). A similar process led to the spatial concentration of the lowstatus population in the former agro-towns of the Great Hungarian Plain, where scattered farm areas with poor accessibility became the main migration targets of socially excluded people (Romány, 1973; Csalog, 1984; Vasárus, 2016).

Some processes from the communist era continued after the political and economic transition, and the now less controlled mobility also contributed to the emergence of new trends. Population succession and selective migration between preferred or non-preferred locations within settlements once again reproduced residential segregation. The higher-income groups of the local societies moved to the suburbs, whereas low-status residents migrated to peripheral villages mostly outside of the agglomerations, which intensified the spatial separation of these social groups. The steadily increasing share of the Roma population in these villages led to a new type of segregation in Hungary, with entire microregions almost exclusively consisting of deprived social groups (Virág, 2010). These people were excluded from the labour market and even lost their ambitions in life. Because of this, János Ladányi and Iván Szelényi (2004) describe this process as the birth of the rural underclass. The result of a field survey headed by István Kemény and Béla Janky (2004) shows that $72 \%$ of Roma families lived in residential segregation in 2003. A national survey conducted in 2010 also yielded similar results. In the 823 settlements and ten metropolitan districts of Budapest investigated, there were 1,623 neighbourhoods where low-status or Roma people lived in residential segregation (Domokos \& Herczeg, 2010). These recent surveys and other studies indicate that the integration process that began during the era of state socialism has been interrupted in Hungary, and that after the political transition the issue of residential segregation is again becoming more pressing.

\section{Methodological background}

\subsection{Study area}

The Southern Great Plain statistical region is located in southeast Hungary and has a population of 1.3 million, which is $13.2 \%$ of Hungary's total population. The exact number is $1,262,936$ people $(602,183$ men and 660,753 women) according to the 2015 Hungarian microcensus. Three counties constitute the region: Bács-Kiskun, Csongrád, and Békés. Despite the low population density of seventy-two people per square kilometre, $67.9 \%$ live in municipalities with town rights. Although this statistically makes the Southern Great Plain statistical region one of the most urbanised regions of the country, in many aspects it can be considered more rural than urban. The unique elements of the settlement network (market towns with garden neighbourhoods and scattered farms) also underscore this characterisation (Figure 1).

The main elements of the settlement structure are specialised market towns known as agro-towns. Originally these agrotowns were the centres of agricultural production and markets. Under Ottoman rule, they enjoyed protected status and, unlike smaller villages, they avoided destruction. After Ottoman rule, this resulted in a very sparse settlement network consisting of almost exclusively agro-towns. Distant patches of arable land could not be cultivated from the agro-town centres, and so a unique scattered farm system was developed. These scattered farms (called tanya in Hungarian) were originally inhabited only periodically and served as auxiliary settlements with close ties to their agro-town. This connection later weakened and the scattered farms became permanent residences. The population of the towns' outskirts reached a peak only after the Second World War, and by then the unique dual nature of agro-towns and scattered farms had long faded, and the development of the scattered farm clusters into villages was in an advanced state. In the last fifty years, the number of people living on the outskirts significantly decreased from around one million to about three hundred thousand in 2011 for the entire country. There are spatial differences in this process and in the Southern Great Plain statistical region - especially in the Danube-Tisza interfluve or in Békés County - the percentage of the population living on the outskirts is still higher than the national average. 


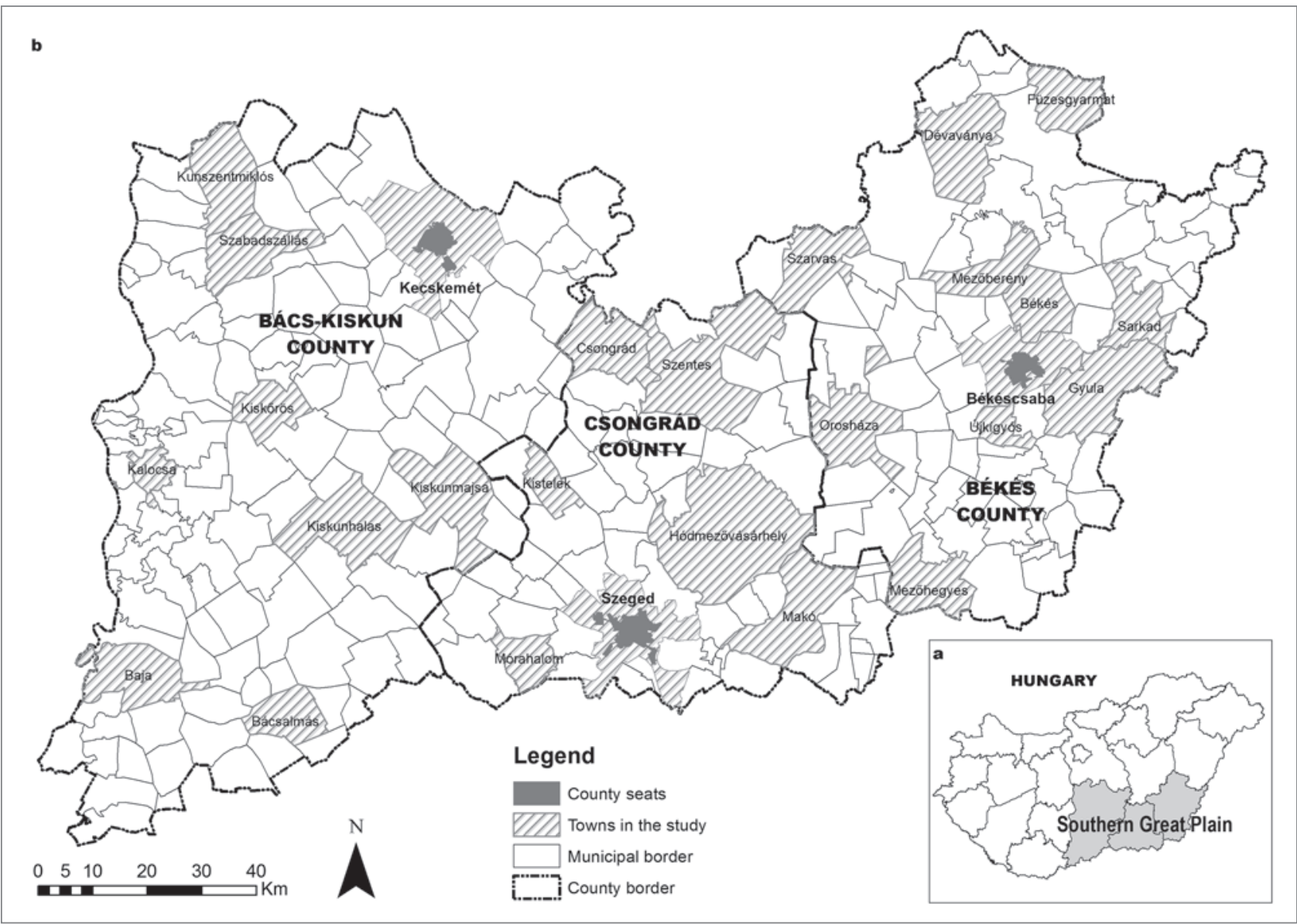

Figure 1: a) geographical location of the region examined in Hungary; b) the towns examined (author: Jenő Zsolt Farkas).

During the communist era, the industrialisation process reached the market towns to a various extent. The towns with a larger population lost their primary agricultural functions and now became industrial and tertiary sector centres. One of the most important regional centres is Kecskemét, with a population of 117,000 . This town has become a unique "traditional agro-town" over the past few years because of the large foreign investment in the region, which was made by the Daimler Group in 2009, when a Mercedes-Benz factory was established here. This investment allowed the town authorities to rehabilitate housing blocks based on the needs of the town and Mercedes-Benz. This was a special opportunity because otherwise EU grants define such opportunities. This was the main reason why we chose Kecskemét as a case study, and the second reason, as described below, is because all of the spatial forms of residential segregation can be found in this agro-town (Figure 2).

Kecskemét has a 650-year history as a town, and the formation of its urban districts was affected by many environmental and social factors. In the early years, there were no established spatial structures or functional districts. Starting at the begin- ning of the fifteenth century, the first signs of differentiation can be seen between the districts, especially in the residential ones formed during this period. The wealthier inhabitants lived in the centre, which corresponds to today's main square and the surrounding area. The less well-off population lived in a sharp separation around the periphery of the built-up area. Starting in the mid-eighteenth century, population growth caused further differentiation of the local society and the typical form of residential segregation appeared during this period. Because of frequent fires, the authorities introduced building regulations (Juhász, 1998). The main elements of this were street planning and building material codes. The material codes stipulated that in the town centre builders were only allowed to use brick for construction, which the poorer families were unable to buy. Because of this, the authorities designated building areas for them on the periphery of the built-up area. These included mainly low-lying areas that would periodically flood. Consequently, these areas had poor accessibility and the living conditions were unhealthy because the walls of the houses were permanently wet. The residential segregation of the low-status and Roma people generated various problems in the local society in those days. This was also the period when scattered farms formed on the outskirts. 


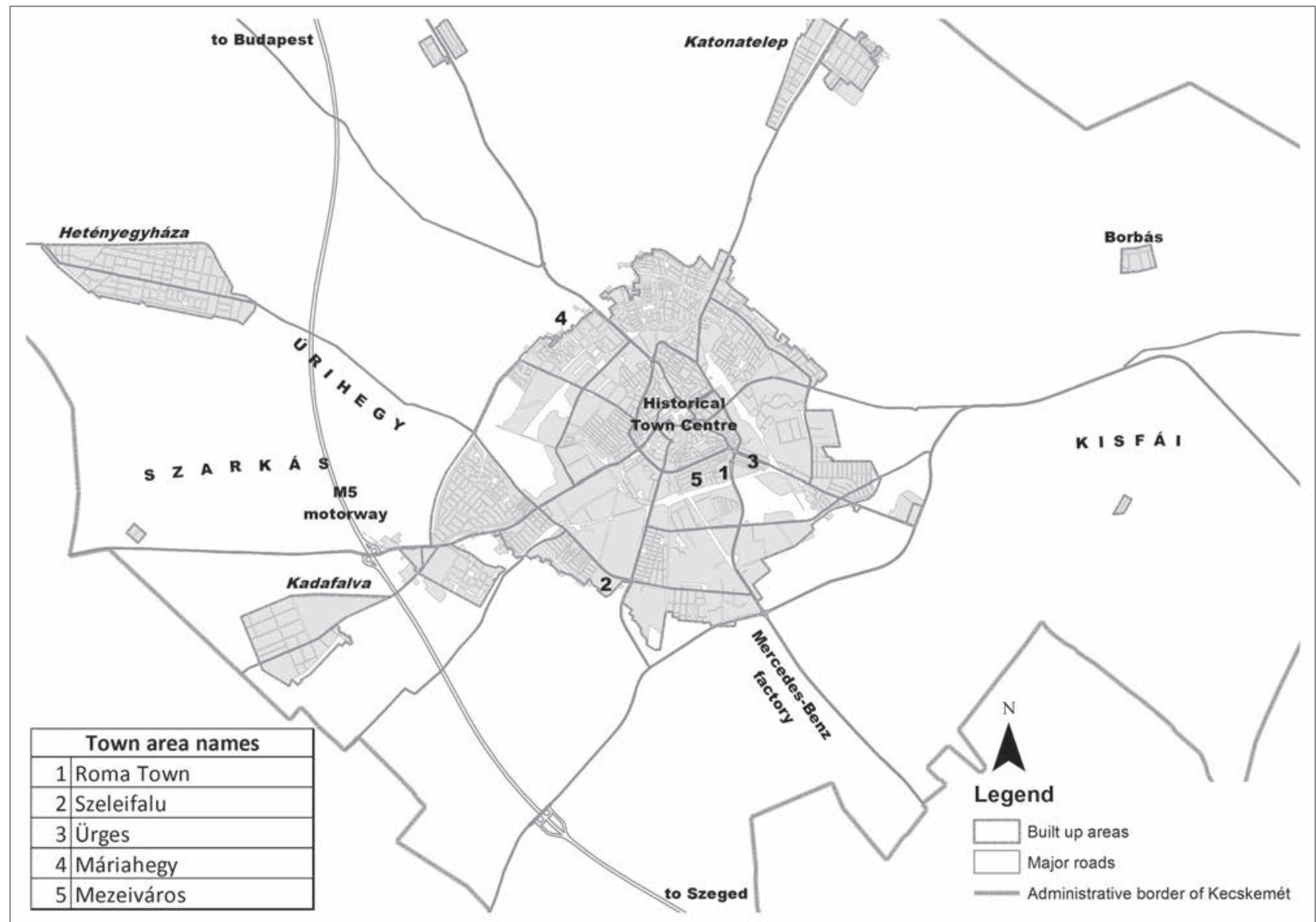

Figure 2: The Kecskemét area with the geographical names used in the study (authors: Jenő Zsolt Farkas \& András Donát Kovács).

Until the First World War, there was remarkable development of industry and the agricultural market in Kecskemét, but in spite of this the town centre essentially remained the core of a large village. Its "metropolitan image" did not spread to the residential areas, and the segregated areas on the periphery further strengthened its rural image. Between the two world wars, the economic function of the town shifted from an agricultural centre to a more modern agro-industrial regional centre. This process also changed the employment structure of the population. During the Great Depression (1929-1933), the economy stagnated and broke the development course of Kecskemét. This caused social problems in local society such as general impoverishment, which led to increased social differences and exacerbated residential segregation. Thousands of people moved into adobe houses during those years. The most distinct segment of the local society has always been the Roma people, whose assimilation attempts were unsuccessful. Their geographically isolated ghetto, called Cigányváros 'Roma Town', was only demolished in 1963, in accordance with the general policy of the communist state. The town authorities had to provide new homes for more than a thousand people. They distributed building sites at the edge of the built-up area and they also moved families to the town centre, where they were allotted old houses in poor condition. Many families that received building sites purchased dwellings in blocks of flats with loans some years later or moved to the surrounding villages.

During the transition from communism, new Roma families from other settlements moved to the former Roma Town shanties. As a result, the percentage of the Roma population began to increase in some street blocks in the wider area of the former Roma neighbourhood, whereas the majority ethnic population moved to newly built condominiums or to new garden city areas and suburbs. This was the last step that led to the current problematic situation, in which the Roma once again live under strong residential segregation, leaving a unique imprint on the fabric of the town.

\subsection{Methods applied}

We used several different methods to answer the research questions: document and GIS analysis, interviews and field surveys. For the regional overview of residential segregation, we reviewed the Integrated Urban Development Strategies of twenty-seven towns in the Southern Great Plain statistical 


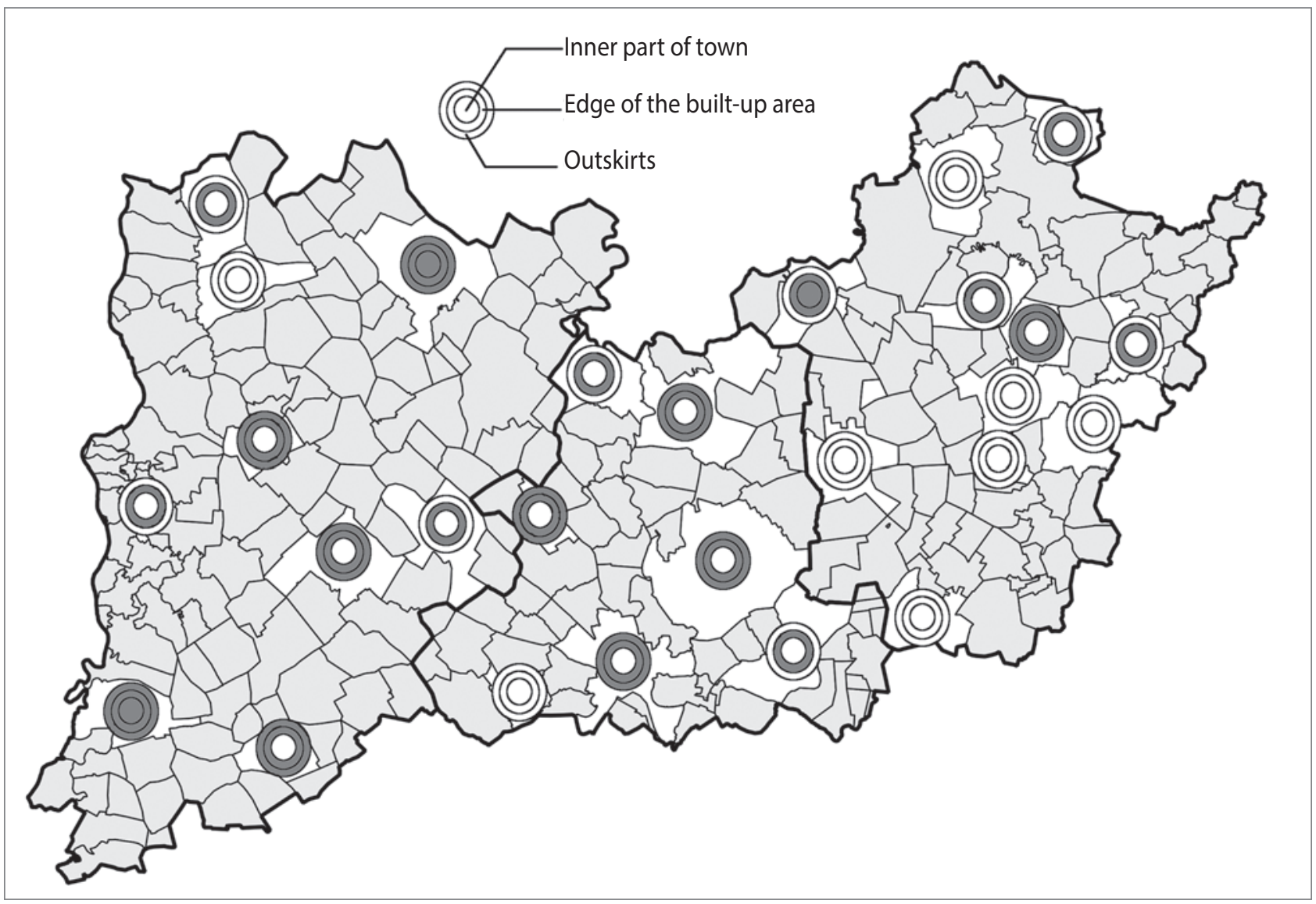

Figure 3: Locations of residential segregation in the towns examined (author: József Lennert).

region. These documents are available on the Térport website (Internet 1). The results of these strategies are comparable to each other because the "anti-segregation plans" applied a common, centrally developed methodology by the Ministry of Local Government and Regional Development (Internet 2). We also used similar methods to analyse residential segregation in Kecskemét. The segregated residential neighbourhoods of Kecskemét were first officially identified in the Anti-Segregation Plan of the Integrated Urban Development Strategy in 2008. The authors of this article had a major role in that assessment, in which eight segregated neighbourhoods were identified in Kecskemét (Internet 3). At that time the identification method was based on the publication Városrehabilitáció 2007-2013-ban Kézikönyv a városok számára (Urban revitalisation in 2007-2013: Handbook for towns; Internet 2). A few years later, in 2014, we continued these examinations because the town was required to reassess its segregated neighbourhoods. The methodology was developed by the Ministry of National Development and the Economy, and it was released in 2009 as the second edition of the handbook (Internet 4 ). There were two ways to identify segregated residential neighbourhoods according to the handbook:

- Street blocks where at least $50 \%$ of the population age fifteen to fifty-nine have no regular income from work and did not graduate from primary school (fewer than eight years of primary school),

- Street blocks where the share of welfare recipients is more than twice the town average.

In addition to these, there is another important condition in the handbook, which states that a segregated residential neighbourhood must include at least fifty residents. This restriction eliminates the distorting effect of individual cases. Our analysis shows that most towns in the region used both of these criteria in their development strategies, as we did in the case of Kecskemét. In the case study of Kecskemét, we also used the 2013-2015 Kecskemét Urban Development Strategy (Internet 5), the 2014-2020 Anti-Segregation Plan for Kecskemét (Internet 6; we took part in these as authors), the 2011 census data and databases from the Urban Development Agency of Kecskemét, which contained the datasets for social care and assistance. The census data come from the Hungarian Central Statistical Office (HCSO); these data were already geocoded and pointed to possible segregated residential neighbourhoods. The social sector raw datasets first had to be geocoded, and after that we were able to identify possible locations of low-status people and to crosscheck these areas with the data from the HCSO. The geocoding process and 
the related spatial analysis were carried out using ArcGIS desktop software (Internet 7). To better understand the processes in the segregated neighbourhoods identified, we carried out thirty-four in-depth interviews with the town representatives, the urban development agency, social workers and members of the Roma ethnic group. We also investigated other related town documents and project activity in this area.

\section{Results}

The analysis of the development documents confirmed our previous experiences from Kecskemét. The concentration of low-status people shows a triple spatial division inside the administrative borders of the agro-towns examined. Such concentrations can occur in three locations: 1) town centres, 2) the edges of built-up areas and 3 ) on the outskirts (Figure 3 shows them for each town examined).

As already described in the case of Kecskemét, these areas underwent different historical segregation processes and their statuses are also very different today. The features of these areas can be summarised as follows.

Residential segregation in the inner part of the town shows the closest connection with the concentric urban ecology model of Robert Ezra Park et al. (1925). In their study they found a segregated residential neighbourhood around the central business district of Chicago. There are only three similar hotspots in the agro-towns of the region (Baja, Kecskemét and Szarvas), which means that this form of residential segregation is not typical in the Southern Great Plain statistical region. The general reasons behind this are the relatively small area of the town cores, a lack of old buildings (i.e., no places for low-status people) and finally the permanence of slums on the edge of built-up areas. Suburbanisation (which began in the 1980s) also plays a role in towns with a larger population (Mészáros, 1990; Timár, 1993). In these cases, high-status people have moved out from their dwellings to the outskirts or to the surrounding villages and this process allowed low-status (mainly Roma) people to move into these places. Because of the differences in the sub-structures of the three towns, the living conditions are very different. In Baja, the Roma people also live in the inner courtyards of the houses, which is very similar to what can be seen in downtown Budapest. In Szarvas, they moved into a detached housing area with gardens, and there are many smaller segregated areas in the town centre of Kecskemét, which now forms a corridor to the historical Roma areas in the southeast.
From the twenty-seven identified instances of segregation in towns of the Southern Great Plain statistical region, nineteen lie on the edge of built-up areas, which makes this the most typical form of residential segregation. The most populous Roma neighbourhood (2,959 people in 2001) can also be found in such locations in Makó. These concentration points of low-status people have evolved throughout the history of the towns. In some cases, these areas were demolished in the communist era (as in Kecskemét and Szentes), but one can still find such blocks in a close geographical location. The cause of this is an erroneous practice by the town authorities, who moved these people to a similar new place in the neighbourhood in a closed group, and so they only relocated the problem. The $C s$ houses are the typical markers of these neighbourhoods. The environmental conditions are unfavourable (high groundwater levels), which causes problems in everyday living conditions (such as mouldy walls). The infrastructure of these areas is generally in poor condition or lacking. Sometimes the town residents only know these areas by historical "nicknames" such as Kis Bécs 'Little Vienna' in Makó or Krakkó 'Krakow' in Szarvas. Sársziget 'Mud Island', the low-prestige segregated area of Füzesgyarmat, consists of Foundation for Folk and Family Protection (Hungarian: $O N C s A$ ) houses, which were built during the Second World War to assist large families. This example illustrates that geographical segregation can also develop from special residential areas originally built with positive intentions.

The last concentration location of the low-status people is the outskirts of the agro-towns. Among the twenty-seven development strategies analysed, we found ten in which the authors made reference to this problem or identified a segregated residential neighbourhood on the outskirts (e.g., in Baja). During the communist era, the official policy was to eliminate these scattered farms, and so there was a building restriction until 1986. Thus the scattered farm buildings are generally in poor condition and uncomfortable because they were mainly built before the 1950s. The population is ageing, is poorly educated and has a high unemployment rate, and many people are living in poverty. Despite the poor situation of the native population, these areas are migration targets for low-status people from towns. These newcomers often have large families with many children. Their relocation is an attempt to escape urban poverty, and so they can be considered social migrants. They hope that the expenses of everyday living will be lower there, but they do not know how to manage the small farms around the houses, and so these expectations are unrealistic. The original inhabitants often see a connection between newcomers and crime in the scattered farm areas. In the case of Szentes, there have been news reports about homeless people occupying the vacant scattered farms near the town. 


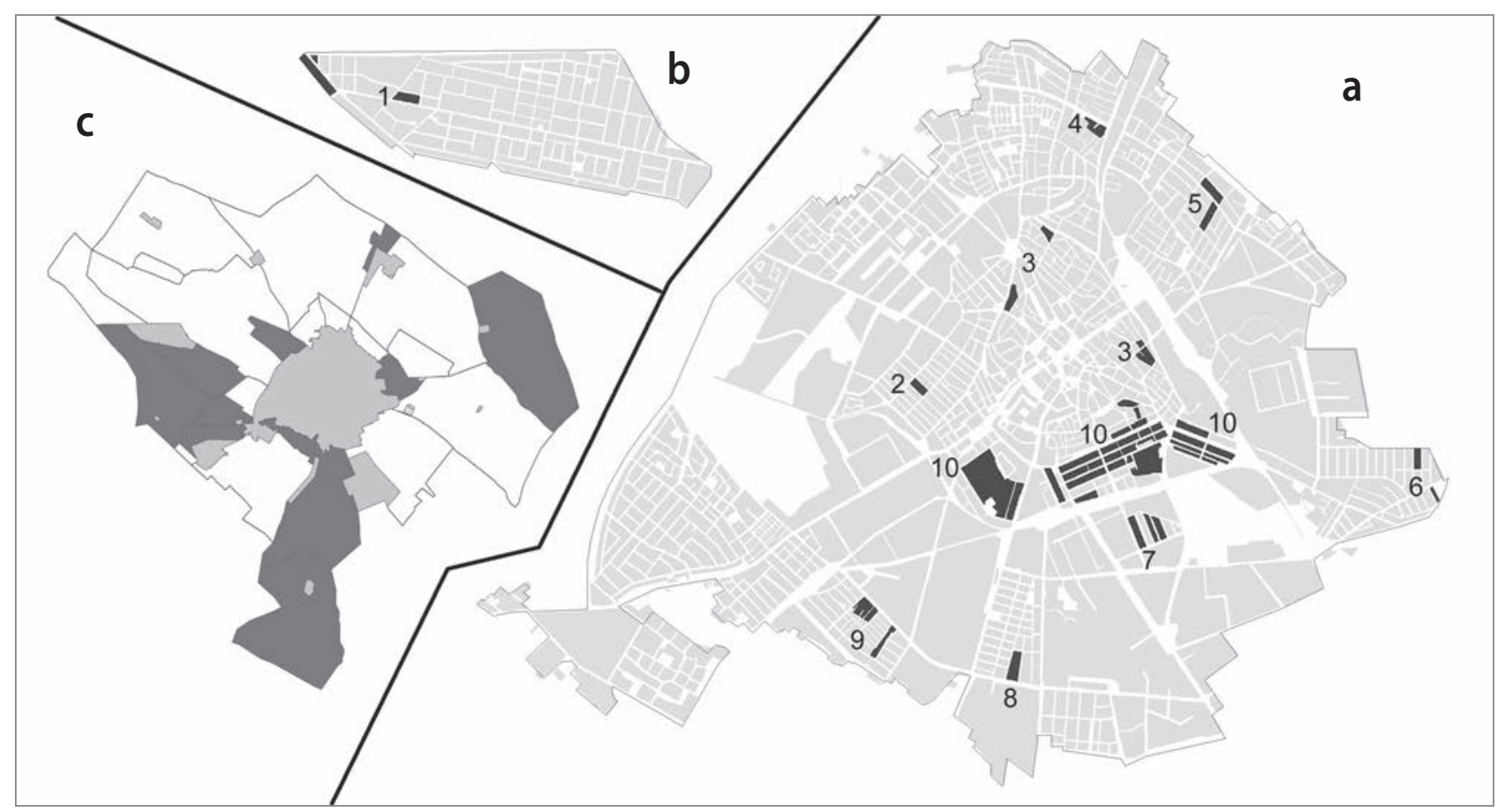

Figure 4: a) location of segregated neighbourhoods in Kecskemét; b) the Hetényegyháza area in the suburbs and its segregated blocks; c) the outskirts with the most segregated scattered farms (authors: József Lennert, Jenő Zsolt Farkas and András Donát Kovács; based on data from HCSO 2016 and the 2011 census).

\section{Case study of Kecskemét}

\subsection{Locations of segregated residential neighbourhoods}

Based on our examination following the methods described above, we determined the following segregated areas in Kecskemét: 1) blocks in the Hetényegyháza area, 2) blocks of Téglagyár utca (Brickworks Street), 3) separated blocks in the downtown area, 4) a block along Nagy Lajos király körút (King Louis the Great Street), 5) residential block beside Mátyás király körút (Matthias Corvinus Street), 6) blocks in the Mükertváros area, 7) blocks in the Muszáj area, 8) blocks of Löcsei utca (Löcsei Street), 9) blocks in the Szeleifalu area and 10) the southern part of the town centre. These areas are numbered in Figure 4a. Figure $4 \mathrm{~b}$ shows the suburban district of Hetényegyháza and its segregated blocks. Figure $4 \mathrm{c}$ shows the disadvantaged outskirts in a darker shade.

\subsection{Condition of residential buildings in segregated neighbourhoods}

The built environment of the segregated neighbourhoods often reveals the negative social processes in these areas. There are many run-down buildings, some of them are in life-threatening shape, yet they were inhabited until recently. There are also illegal waste dumps in many vacant lots and signs of vandalism on the buildings or on the street furniture. Because of these general conditions, the real estate prices are low not only in these neighbourhoods but in their surroundings as well. The most critical conditions can be found in the blocks where Roma people make up the majority of the local residents.

The formation and persistence of segregated areas largely depend on the age of the buildings and their condition (which are interdependent to some degree). There are 49,665 flats and homes in Kecskemét, among which eight thousand (16.3\%) are over fifty years old according to the HCSO statistics. Among these, 3,057 do not meet comfort standards (comprising 6.1\% of all housing). The majority of these dwellings can be found in segregated neighbourhoods, and without housing renovation they will continue to attract only low-status settlers and further strengthen the negative processes. Because of their special attributes, the status of the buildings owned by the local government should be analysed separately. In 2012, 1,596 flats were owned by the local government. Among these, six hundred houses with mostly low comfort standards were used for social housing. The number of flats retained for social housing shows a decreasing trend (in 2016 there were 508 flats) and the majority can be found in segregated neighbourhoods. The major problem is the rental fees because they do not cover the maintenance costs, which means that the town's property management company cannot maintain the current conditions of these buildings. This is why the condition of these dwellings is steadily deteriorating. 


\subsection{Characteristics of segregated neighbourhoods with an ethnic majority and attempts at a solution}

The largest segregated neighbourhood with a Roma majority is the aforementioned Roma Town, which has been located southeast of the town centre for centuries (Figure 5). In the 1960s and 1970s, the spatial concentration of the Roma decreased because of attempts to demolish some of the blocks in this area. After 1990, the local government liquidated the temporary accommodation housing in the town core (these were the "Roma courtyards") and the residents moved back to the surroundings of Roma Town. This process resulted in the renewal of the old segregated residential neighbourhood and also the deterioration of the buildings.

Due to the worsening housing situation of the Roma, the local government started a program in 2002 to move them out from the town-owned shanties. The involved two hundred Roma families (30\% of all of the Roma in the town) could choose between two alternatives: a home exchange or purchase of lease rights. Because these shanties had no market value, the local government offered the modest sum of EUR 5,700 to every family for lease rights. The hundred families that choose this option were only able to afford "vacation houses" or farm buildings on the outskirts. The interviewees stated: "In this way, getting rid of the shanties only moved the minority issues to the outskirts, negatively affecting the neighbourhoods they moved to because of their depreciation."

In 2006 the program was continued and fifty families took part in it. This time the majority of families choose the exchange option and left their houses. Although these measures temporarily mitigated the segregation of the Roma, the spatial patterns of residential segregation were soon reproduced. Employment opportunities attracted new Roma families from other towns, who mostly moved to the streets in the neighbourhood of the former shanties because of the lower property prices.

In order to address this problem, the town council started an Integrated Social Urban Rehabilitation Programme, which was supported by the EU through the South Great Plain Operational Programme. The aim of this project was to promote social integration for Roma living in the Mezeiváros and Ürgés neighbourhoods. As part of social integration, the urban development agency emphasised improving living conditions, renewing public services and strengthening the local identity of the residents. The "hard outputs" of the project were twelve modernised public rental flats, a new multifunctional community centre and the development of public places with new street furniture and road reconstruction. There were additional "soft" or social project elements as well, such as community
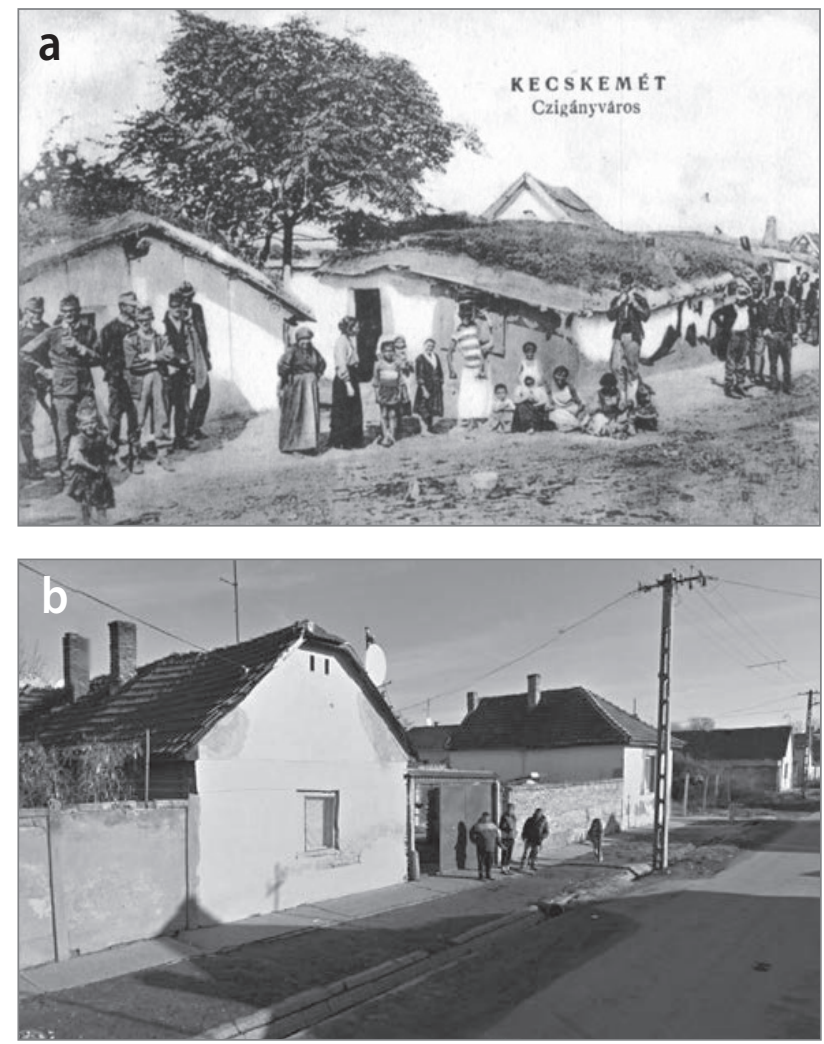

Figure 5: Czigányváros (Roma Town) on a postcard from 1930 (source: Internet 8); b) poor houses in the neighbourhood today (source: Google Street View, 2012).

development, cultural services and family care assistance activities. The follow-up of the project is ongoing and, although there are undoubtedly some positive results, the problem itself has not been resolved.

\subsection{Segregation processes on the outskirts}

One of the possible "escape routes" of the impoverished population leads to the outskirts of agro-towns - specifically, to the scattered farms. This phenomenon can also be observed in Kecskemét, which is the largest agro-town with the most scattered farms. The population of the outskirts was 17,281 according to the 2011 census, or $15 \%$ of the town's residents (111,411 in 2011). In 2001 the population on the outskirts was only 13,732 , and so in the last decade there was a $25 \%$ increase in this number caused by two process: the relocation of low-status people from segregated neighbourhoods to the scattered farms, and the suburbanisation of high-status residents. There are no accurate data or surveys on the proportion, but we estimate that there is an equal split between the two types. The experiences of the interviews and fieldwork indicated that the outskirts of Kecskemét are very fragmented in terms of land-use structure. There are gardens, low-density residential neighbourhoods close to or connected with the built-up area and traditional scattered farms dispersed 
farther from these. Because of this, the processes in the outskirts are very diverse. High-status people occupy the nearby areas (sometimes with luxury residences in the Máriahegy and Úrihegy areas), whereas people from the segregated neighbourhoods are moving further away to the scattered farms. In the last twenty years, both the western and the eastern part of the outskirts were affected (i.e., Szarkás, Borbás and Kisfái), where the share of disadvantaged people significantly increased. Lowstatus people can buy buildings relatively cheaply there because under the state socialism system the development of scattered farms and their buildings was banned until 1986. The original ageing population is also favourable for this outflow because there are many empty buildings that are still suitable for living in, but usually only at a low comfort level.

At the same time, the newcomers do not have the necessary experience for living on a scattered farm, and their employment and the school attendance of their children is becoming increasingly difficult. The original farm population stigmatises them because it feels that public safety has been compromised and it connects them with criminal behaviour in the neighbourhood. The situation is also exacerbated by homeless people occupying vacant properties. These developments pose a challenge to social care organisations because the accessibility of low-status people becomes more problematic.

\section{Conclusion}

Our research indicates that residential segregation is a frequent phenomenon in the agro-towns of Hungary's Southern Great Plain statistical region. These processes share some similarities but are also differ to some degree from the western European or US examples. The role of ethnicity in segregation is the most common feature, and one can draw a parallel between the situation of the Roma in the study area and low-status African Americans in US cities. The attempts at a solution also fail in the same way because the local government is interested in treating only one aspect of this complex problem and only marginally deals with issues of social integration. This causes the continuous reproduction of the phenomenon with the recurrence of social and ethnic segregation in other parts of towns, in many cases in the same location for centuries.

The differences between the western and local manifestations of segregation are mostly due to different settlement morphology. The settlements in the study area are generally smaller than their western and US counterparts. As a consequence, their historical core is also smaller and is often considered valuable by the residents and the local government, and so the occurrence of segregation in the inner parts of towns is limited. On the other hand, segregation on the edge of continuously built-up areas is typical in the towns examined. In some cases, the present-day segregation area is geographically linked to former Roma neighbourhoods, whereas in other cases it developed from other disadvantaged neighbourhoods. The housing stock in the areas of the towns examined is very diverse and has a patchwork character due to the often interrupted and altered course of settlement development. Thus segregation occurs at the street level rather than district level, and so one mostly finds segregated blocks of streets instead of widespread areas.

Another unique phenomenon stemming from the distinct settlement morphology is the occurrence of segregation on the outskirts of the towns. Garden neighbourhoods and scattered farm areas, which are a traditional element of agro-towns, recently became migration destinations for both the low- and high-status population. Whereas the relocation of well-off groups to the rural-urban fringe can be seen as suburbanisation within the municipal boundaries, the low-status groups generally try to reduce their living costs by giving up their homes in the contiguously built-up area. However, without sufficient experience in self-sufficient agriculture, such attempts are usually doomed to fail. Thus the deprivation of the low-status newcomers increases. Moreover, they also lose their previous protective network of contacts and are also now out of sight from organisations that can provide them with social assistance.

Kecskemét is a good example of both historical development and recent trends in residential segregation. In geographical terms, the segregated areas are located close to the former segregated area, Roma Town. There is no major change in the affected residents either, who are mostly Roma. This is partly due to the falsely principled urban development planning of the twentieth century, which treated the minority groups as a closed set. The segregated neighbourhoods have never been entirely removed, and they were never completely uninhabited and always filled up with newcomers. Even the relocations did not ease the situation because people were mostly moved to other disadvantageous locations. The "export" of low-status people to the outskirts is also a typical process in Kecskemét just like in other towns of the Southern Great Plain statistical region.

The analysis of the segregated neighbourhoods in Kecskemét shows a strong correlation between the spatial location of lowstatus people and the physical condition of the buildings. It can also be seen that these areas are located where there is a large quantity of low-standard social housing owned by the local government. Because of this, the town council and the urban development agency play a key role in managing and revitalising the segregated blocks. The main factor hindering the development of these areas is insufficient financial resources 
for the task. Although there are certain targeted EU subsidies for urban renewal, the town cannot carry out comprehensive social development in segregated neighbourhoods without adequate local resources. Apart from the lack of necessary funds, the results of the research also emphasize the importance of complex thinking about residential segregation. The improvement of the living environment in itself is merely the initial step of a social integration process, and social care for low-status people cannot end after infrastructure investments without risking the recurrence of spatial segregation.

\section{Jenő Zsolt Farkas}

Institute for Regional Studies, Centre for Economic and Regional Studies, Hungarian Academy of Sciences, Kecskemét, Hungary E-mail: farkasj@rkk.hu

\section{József Lennert}

Institute for Regional Studies, Centre for Economic and Regional Studies, Hungarian Academy of Sciences, Kecskemét, Hungary E-mail: lennert@rkk.hu

\section{András Donát Kovács}

Institute for Regional Studies, Centre for Economic and Regional Studies, Hungarian Academy of Sciences, Kecskemét, Hungary E-mail: kovacsa@rkk.hu

\section{Imre Kanalas}

Kecskemét Urban Development Ltd., Kecskemét, Hungary

E-mail:kanalasimre@kecskemetivarosfejleszto.hu

\section{Acknowledgments}

The research for this article was supported by the János Bolyai Research Scholarship of the Hungarian Academy of Sciences.

\section{References}

Anthopolos, R., Kaufman, J. S., Messer, L. C. \& Miranda, M. L. (2014) Racial residential segregation and preterm birth: Built environment as a mediator. Epidemiology, 25(3), pp. 397-405.

DOI: 10.1097/ede.0000000000000079

Bellman, B. (2014) Segregation and urban form: Towards an understanding of dynamics between race, population movement, and the built environment of American cities. Bachelor's honours thesis. Available at: http://scholar.colorado.edu/honr_theses/44 (accessed 14 Nov. 2016).

Bjorvatn, K. \& Cappelen, A. W. (2001) Inequality, segregation, and redistribution. Journal of Public Economics, 87(2003), pp. 1657-1679. DOI: 10.1016/S0047-2727(01)00202-X

Bolt, G., Özüekren, A. S. \& Phillips, D. (eds.) (2012) Linking integration and residential segregation. London, Routledge. DOI: $10.4324 / 9780203718490$

Burgess, E. W. (1928) Residential segregation in American cities. Annals of the American Academy of Political and Social Science, 140(1), pp. 105115. DOI:10.1177/000271622814000115

Charles, C. Z. (2001) Processes of residential segregation. In: O'Connor A., Tilly, C. \& Bobo, L. B. (eds.) Urban inequality: Evidence from four cities, pp. 217-271. Russell Sage Foundation. DOI:10.1017/s0022050701005812

Charles, C. Z. (2003) The dynamics of residential segregation. Annual Review of Sociology, 29, pp. 197-207.

DOI: 10.1146/annurev.soc.29.010202.100002

Clark, W. A. V. \& Ware, J. (1997) Trends in residential integration by socioeconomic status in southern California. Urban Affairs Review, 32(6), pp. 825-843. DOI: $10.1177 / 1078087497032006$

Csalog, Z. (1984) A cigánykérdés Magyarországon 1980 előtt. Magyar Füzetek, 14-15, pp. 93-137.

Domokos, V. \& Herczeg, B. (2010) Terra incognita: magyarországi szegény és cigánytelepek felmérése - első eredmények. Szociológiai Szemle, 20(3), pp. 82-99.

Duncan, O. D. \& Duncan, B. (1955a) A methodological analysis of segregation indexes. American Sociological Review, 20(2), pp. 210-217. DOI:10.2307/2088328

Duncan, O. D. \& Duncan. B. (1955b) Residential distribution and occupational stratification. American Journal of Sociology, 60(5), pp. 493-503. DOI:10.1086/221609

Duncan, O. D. \& Duncan. B. (1957) The Negro population of Chicago: A study of residential succession. Chicago, University of Chicago Press.

Farley, R., Elaine L., Fielding, E. L. \& Krysan, M. (1997) The residential preferences of blacks and whites: A four-metropolis analysis. Housing Policy Debate, 8(4), pp. 763-800. DOI:10.1080/10511482.1997.9521278

Gentile, M. (2004) Divided post-Soviet small cities? Residential segregation and urban form in Leninogorsk and Zyryanovsk, Kazakhstan. Geografiska Annaler: Series B, Human Geography, 86(2), pp. 117-136. DOI: 10.1111/j.0435-3684.2004.00157

Glazer, N. \& Moynihan, D. P. (1963) Beyond the melting pot: The Negroes, Puerto Ricans, Jews, Italians, and Irish of New York City. Cambridge, MA, MIT Press. DOI:10.1001/jama.1963.03710110079027

Google Street View (2017) Street View Kecskemet. Available at: https:// www.google.hu/maps/place/Kecskem (accessed 10 Sept. 2017).

Gyenizse, P., Trócsányi, A., Pirisi, G., Bognár, Z. \& Czigány, S. (2016) A multi-factor model developed on residents' opinions for the classification of urban residential areas. Geografie - Sbornik České geografické společnosti, 121(1), pp. 1-31.

Hamnett, C. (2005) Urban forms. In: Cloke, P., Crang, P. \& Goodwin, M. (eds.) Introducing human geographies, pp. 425-438. London, Hodder Education.

Hamnett, C. (2010) Urban inequality and polarization. In: Wu, F. \& Webster, C. (eds.) Marginalization in urban China: Comparative perspectives, pp. 17-28. Houndmills, UK, Palgrave Macmillan. DOI:10.1057/9780230299122_2

Havas, G. (1999) A kistelepülések és a romák. In: Glatz, F. (ed.) A cigányok Magyarországon, pp. 163-204. Budapest, MTA.

Howell, A. J. \& Timberlake, J. M. (2014) Racial and ethnic trends in the suburbanization of poverty in U.S. metropolitan areas, 1980-2010. Journal of Urban Affairs, 36(1), pp. 79-98. DOI: 10.1111/juaf.12030

Hungarian Central Statistical Office (2008-2016) Statistical yearbooks. Budapest.

Hungarian Central Statistical Office (2011) Population Census. Budapest. Illyés, G. (1936) Puszták népe. Budapest, Nyugat.

Internet 1: http://www.terport.hu/telepulesrendezes-fejlesztes/fejlesztesi-dokumentumok (accessed 11 Jan. 2017). 
Internet 2: http://www.sze.hu/ lados/NGB_RT015/varosfejlesztesi_ kezikonyv_071004_vegleges_fin.pdf (accessed 11 Nov. 2016).

Internet 3: http://kecskemetivarosfejleszto.hu/letoltesek/KecskemetMJV_IVS.pdf (accessed 11 Jan. 2017).

Internet 4: https://www.palyazat.gov.hu/download.php?objectld=38840 (accessed 12 Jan. 2017)

Internet 5: http://www.kecskemet.hu/ivs/20121207_Kecskemet_felulvizsgalt_Integralt_Varosfejlesztesi_Strategiaja_2012.pdf (accessed 15 Jan. 2017).

Internet 6: http://kecskemetivarosfejleszto.hu/wp-content/uploads/2017/01/KMJV_ITS_2014090.pdf (accessed 1 Dec. 2016).

Internet 7: http://www.esri.com/arcgis/about-arcgis (accessed 21 Mar. 2014)

Internet 8: http://ciganyokrol.blog.hu/page/10 (accessed 10 Sept. 2017).

Juhász, I. (1998) Kecskemét város építéstörténete, Kecskeméti Füzetek 8. Kecskemét, Tiberias Bt.

Kállai, E. \& Törzsök, E. (eds.) (2006) Átszervezések kora. Cigánynak lenni Magyarországon. Budapest, EOKIK.

Kemény, l. (ed.) (2000) A magyarországi romák. Változó Világ 31. Budapest, Press Publica.

Kemény, I. \& Janky, B. (2004) Települési és lakásviszonyok. Beszélő, (9)4, pp. 96-102.

Kocsis, K. \& Kovács, Z. (1999) A cigány népesség társadalomföldrajza. In: Glatz, F. (ed.) A cigányok Magyarországon, Magyarország az ezredfordulón, pp. 13-21. Budapest, MTA.

Kovács, Z. (2012) Residential segregation in Budapest before and after transition. In: Maloutas T. \& Fujita, K. (eds.) Residential segregation in comparative perspective: Making sense of contextual diversity, pp. 197216. London, Routledge.

Ladányi, J. \& Szelényi, I. (2004) A kirekesztettség változó formái. Budapest, Napvilág Kiadó.

Lieberson, S. (1963) Ethnic patterns in American cities: A comparative study using data from ten urban centers. New York, Free Press.

Lloyd, C. D., Shuttleworth, I. G. \& Wong, D. W. (eds.) (2014) Social-spatial segregation: concepts, processes and outcomes. Bristol, The Policy Press. DOI: 10.1332/policypress/9781447301356.001.0001

Logan, J. R. \& Stults, B. J. (2011) The persistence of segregation in the metropolis: New findings from the 2010 Census. US2010 Project. Available at: http://www.s4.brown.edu/us2010/Data/Report/report2.pdf. (accessed 10 Sept. 2017).

Logan, J. R., Stults, B. J. \& Farley, R. (2004) Segregation of minorities in the metropolis: Two decades of change. Demography, 141(1), pp. 1-22. DOI:10.1353/dem.2004.0007

Maloutas, T. \& Fujita, K. (eds.) (2012) Residential segregation in comparative perspective Making sense of contextual diversity (Cities and Society series), London, Routledge. DOI: 10.4324/9781315605661

Marcuse, P. (1997) The enclave, the citadel, and the ghetto: What has changed in the post-Fordist U.S. city. Urban Affairs Review, 33(2), pp. 228-264. DOI: 10.1177/107808749703300206

Márquez, F. (2011) Santiago: Modernisation, segregation and urban identities in the twenty-first century. Urbani izziv 22(2), pp. 86-97. DOI: 10.5379/urbani-izziv-en-2011-22-02-002

Massey, D. S. \& Denton, N. A. (1988) The dimensions of residential segregation. Social Forces, 67(2), pp. 281-315. DOI: 10.2307/2579183
Massey D. S. \& Denton, N. A. (1993) American apartheid: Segregation and the making of the underclass. Cambridge, MA, Harvard University Press.

Mészáros, R. (eds.) (1990) Az urbanizáció térbeli folyamatai Szegeden. Szeged, JATE.

Morgan, B. S. \& Norbury, J. (1981) Some further observations on the index of residential differentiation. Demography, (18)2, pp. 251-256. DOI:10.2307/2061097

Musterd, S. (2003) Segregation and integration: A contested relationship, Journal of Ethnic and Migration Studies, (29)4, pp. 623-641. DOI: 10.1080/1369183032000123422

Musterd, S. \& Ostendorf, W. J. M. (1998) Urban segregation and the welfare state: Inequality and exclusion in western cities. London, Routledge. DOI: 10.4324/9780203448533

Park, R. E., Burgess, E. W., McKenzie, R. D. \& Wirth, L. (1925) The city: Suggestions for investigation of human behavior in the urban environment. Chicago, University of Chicago Press.

Romány, P. (1973) A tanyarendszer ma. Budapest, Kossuth.

Sabater, A. \& Finney, N. (2014) Demographic understandings of chang es in ethnic residential segregation across the life course. In: Lloyd, C. D., Shuttleworth, I. G. \& Wong, D. W. (eds.) Social-spatial segregation: concepts, processes and outcomes, pp. 269-300. Bristol, The Policy Press. DOI:10.1332/policypress/9781447301356.003.0012

Schelling, T. C. (1971) Dynamic models of segregation. Journal of Mathematical Sociology, 1, pp. 143-186.

DOI: 10.1080/0022250x.1971.9989794

Schelling, T. C. (1978) Micromotives and macrobehavior. New York, W. W. Norton.

Spielman, S. E. \& Harrison, P. (2013) The co-evolution of residential segregation and the built environment at the turn of the 20th century: A Schelling model. Transactions in GIS, 18(1), pp. 25-45. DOI:10.1111/tgis.12014

Szabó, Z. (1937) Cifra nyomorúság: a Cserhát, Mátra, Bükk földje és népe. Budapest, Cserépfalvi.

Taeuber, K. F. \& Taeuber, A. (1965) Negroes in cities: Residential segregation and neighborhood change. New York, Aldine.

Timár, J. (1993) Az alföldi szuburbanizáció néhány sajátossága. Alföldi Tanulmányok, 15, pp. 217-232.

Vaattovaara, M. (2002) Future developments of residential differentiation in the Helsinki metropolitan area: Are we following the European model? Yearbook of Population Research in Finland, 38, pp. 107-123.

Vasárus, G. (2016) Külterületi szuburbanizáció és szegregáció: Példák vidéki agglomerációk konfliktusaira. Településföldrajzi tanulmányok, 6(1), pp. 84-94.

Virág, T. (2010) Kirekesztve: falusi gettók az ország peremén. Budapest Akadémiai Kiadó.

Watson, T. (2006) Metropolitan growth, inequality and residential segregation by income. In: Burtless, G. T. \& Pack, J. R. (eds.) Brookings-Wharton Papers on Urban Affairs, 1, pp. 1-52. DOI:10.1353/urb.2006.0029

White, M. J. (1983) The measurement of spatial segregation. American Journal of Sociology, 88(5), pp. 1008-1018. DOI: 10.1086/227768

Zhang, J. (2006) A dynamic model of residential segregation. Journal of Mathematical Sociology, 28, pp. 147-170. DOI:10.1080/00222500490480202 